\title{
Literackie okruchy religijnych peregrynacji Brytyjczyków w Polsce (do początków XVIII wieku)
}

Beata Cieszyńska 
nAPOS Seria XI 2005

\section{Beata Cieszyńska}

\section{Literackie okruchy religijnych peregrynacji Brytyjczyków w Polsce (do początków XVIII wieku)}

\section{Brytyjczycy w dawnej Polsce. Typy relacji a ich owoce}

W świetle dotychczasowych kwerend takie teksty literackie będące efektem bezpośrednich kontaktów mieszkańców Wysp Brytyjskich z Polakinni i Polskį̨', których podstawą czy tworzywem byłaby podróż, nie stanowią obszerniejszej kolekcji. Stąd tytuł niniejszych rozważań spełnia podwójną funkcję: wyznacznika ilości oraz formalnego wymiaru opisywanych „drobiazgów”. Te ostatnie to czasem dosłownic „okruchy okruchów”, teksty zaginione, rekonstruowalne jedynie na podstawic innych świadectw? ${ }^{2}$.

Znacznie bogatszy zbiór stanowią teksty będące świadectwem kontaktów pośrednich, wplywu kulturowego i religijnego Polski w krajach Wielkiej Brytanii. Dotyczy to zwlaszcza targanej rewolucjami i kryzysami polityczno-religijnymi Anglii, w XVII stuleciu traktującej Rzeczpospolita jako źródlo wzorców i porównań po obu stronach zarysowującego się tam coraz ostrzej podziału sceny politycznej”. Podobny charakter miala literatura okolicznościowa związana z „odsieczą wiedeńską"t.

\footnotetext{
I Panoraniczny zarys relacji handlowych. politycznych oraz kulturalıych miçdzy Wielką Brytanią a Rzccząpospolitą do wicku XVI czytclnik znajdzic w książce I Icuryka Zinsa: Polska u oczadh Anglikéu". XI'-XI'I u'ick. Lublin 2002: natomiast w XVII wicku w cyklu ksiązek Edwarda A. Mierzwy, zchranym

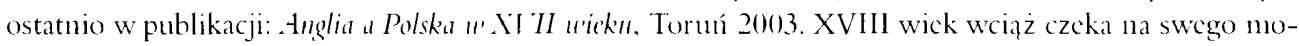
nografistę.

"Choć kategoria okruchów „zaginionych” w większym stopniu odnosi siç do tekstów politycznych.

${ }^{3}$ Zob. C. V. Wedgwood. Poetry and Politics under the Stuarts. Cambridge 1960), s. 7, 87; C. W. Previte-Orton, Political Satrive in English Poetry. Cambridge 1910, rozdz. 3: De'relopme'nt of Party Satire: H. Walker, English Satire and Satirists. London 1925, s. 120.

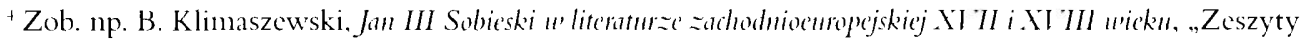
Naukowe Uniwersytetu Jagiellońskiego” t. 6ว̄1, Kraków 1983.
} 
Ów „deficyt świadectw” kontaktów bezpośrednich dotyczy zwłaszcza Irlandczyków. O ile Anglicy podróżowali w tym czasie do Polski w celach dyplomatycznych i handlowych, Szkoci zaś szukali u nas tolerancji, nobilitacji lub też chleba jako domokrążcy czy najemni żołnierze, o tyle pierwszy pisemny zapis podróży Irlandczyka do Polski pochodzi dopiero z końca XVII wiekı i jest dzietem Bernarda O'Connora, lekarza Jana III Sobieskiego ${ }^{5}$. Fakt ten zaskakuje badaczy kultury irlandzkiej, skłonnych zakładać latwość identyfikacji Irlandii z Polską jako krajem katolickim o tradycjach wolnościowych ${ }^{6}$.

Analizowany poniżej materiał przykładowy skupia się na świadectwach bezpośrednich kontaktów kulturowych, powstałych w efekcie podróży jako zjawiska kulturowego, istniejącego w jednym z rozpoznawalnych ówcześnie kodów ${ }^{7}$. Typ ten pozwala na ukazanie różnorodności formalnej i tematycznej istniejących zapisów, obejmujących odmienne gatunkowo utwory odnoszące się do idei Polski jako „państwa bez stosów”.

Przyjęte kryterium doboru wyłącznie tekstów-świadectw pewnej lub prawdopodobnej docelowej podróży, czy szerzej: bytności Brytyjczyka w Polsce, i jej religijnego kontekstu, sprawiło, że w ramach artykułu nie zmieścily się teksty stanowiące zapis przeżycia polskości w sensic bardziej symbolicznym, takie jak na przykład poemat Packa Richardsona U Religions Solitude. Occasion'd by Reading the Inscription on the Tomb of Casimir King of Poland, zapis refleksji angielskiego poety przy nagrobku Jana Kazimierza". Podobny los spotkał literackie efekty podróży dyplomatycznych do Polski, odzwierciedlonych w poezji funeralno-laudacyjnej, zaginionych dramatach typu "dziennikarskiego”, poezji wspomnieniowej oraz .papierowych wojnach” wewnętrznych na Wyspach Brytyjskich, a także literaturę ja-

\footnotetext{
'Wydat on swą w'spomnicniową History' of Poland in Several Letters to a Person of Quality' na fali zainteresowań Polską wzbudzoncj przez wydarzenia interegnum po śmierci Jana III. Nawet on zostal jednak „naturalizowanym" Anglikiem. przeszedl na anglikanizm, ukrywając swą irlandzką tożsamość wraz z wyrzuceniem .. O” sprzed nazwiska. Mówila o tym szerzej Róisin I lealy w referacic Poland and Ireland, I ictims . Alike? Irish Perspectines on the Polish-Lithmanian Commonnecelth in the Eightechth Century' na konferencji Brituin and Poland-Lithania before the year 1795. Contatot and Comparison. Kraków, 15-17 września 2005 (tom konferencyjny w przygotowaniu).

"Zob. Dalitz and Stone, Doctor Bermard Comnor: Physician to King Jan III Sobieski and Author of "The History' of Poland" (1698), .Oxford Slavic Papers" 1981, s. 14-35.

Kody wędrówck w dawnej kulturze zob. J. Abramowska, Peregry'nuje. w: cadem. Pourtórzenia i i'ybory, Warszawa 1995.

"Określenie z tytulu książki Janusza Tazbira: Państu'o be stosóu'. Szkice z dzicjóu" tolerancji "P Polsce XVI i.XI 11 u'ek'l. Warszawa 1967.

"Zob. P. Richardson. L pon Religions Solitude. Occosion'd by" Reading the Inscription on the Tomb of Casimir King of Poland, uho Abdicated his Crou'n, and spent the Reaminder of his Days in the Abbey of St. Germain's at Paris, where he is interr'd. w: idem. Miscellunies in Ie'rse and Prose, London 1719. Autor posluguje sie zuniwersalizowanym szczególem z polskicj historii. by ująć decyzję ostatnicgo z Wazów o abdykacji w perspektywic parenetyczncj ..osobności" jako wybór doskonalszej, rełigijnej drogi zyciowej. Postçpuje tỵm samym śladami lacińskiego epitafium z pomnika nagrobnego Jana Kazimierza.
} 
kobicką i antyjakobicką — świadectwo kontaktów Brytyjczyków z „polską księżniczką” na wirtualnym tronie zdetronizowanych Stuartów, Marią Klementyną Sobieską" .

Druga grupa tekstów niemieszczących się w przyjętych tu ramach tematycznych to reakcje polskich autorów na obecność Brytyjczyków w Rzeczypospolitej".

Wyodrębnione teksty odnoszą się tematycznie zarówno do obecności w Polsce konkretnych, historycznie rozpoznawalnych lub anonimowych osób, jak i calej stypizowanej grupy narodowej. Przypadek ostatni dotyczy Szkotów. Niemal każdy z analizowanych tekstów, poprzez odstonięcie cclów funkcjonalnych, w perspektywie ogólniejszej pozwala zaakcentować swoistość brytyjskiej perspektywy przywoływania Polski.

\section{Fakty, hipotezy i mistyfikacje — religijne peregrynacje Brytyjczyków w Polsce}

W XVI wieku Polska jako „państwo bez stosów” przyciągała uwagę zarówno angielskich polemistów religijnych (częstokroć krytyczną, z uwagi na rozprzestrzenianie się socynianizmu), jak szukających azylı uciekinierów z obu zmagających się obozów religijnych ${ }^{12}$. Jednak wobec osadzenia na polskim tronie popierającego jezuitów Zygmunta III Wazy oraz postępów kontrreformacji w Polsce ${ }^{13}$, literackie świadectwa tradycyjnej polskiej tolerancji zyskują nowe, krytyczne tony, a jeden z jej przejawów - azyl znaleziony w Polsce przez prześladowaną w Anglii księżnę Suffolk - zostal nawet poddany zabiegowi mistyfikacji, ulatwiającej alegoryzację szeroko znancj historii.

Począwszy od dwudziestych i trzydziestych lat XVII stulecia, Brytyjczycy zaczęli przyglądać się coraz baczniej prześladowaniom protestantów w Polsce, korzystając zarówno z pośrednich źródel wiedzy, jak i świadectw naocznych świadków. W ich reakcjach widoczne byly dwa cele. Po pierwsze, dyskredytacja Rzeczypospolitcj jako kraju należącego do dominium jezuitów, zuienawidzonych przez Wyspiarzy aż do granic fobii ${ }^{1+}$. Po drugie, solidarność i pomoc wspólwyznawcom z Polski, na przyklad poprzez zbiórki pieniędzy na ich

\footnotetext{
"Najwiçkszą część tej grupy tekstów stanowily reakcje na joj uwiçzienic oraz ślub z Jakubem Stuartem. Por. rękopis londyúskicj British Library Kings MS 311: "Satirical poem on the Pretender”; A pocm occasioned by the news of arresting the Princess Sobveski, and her being affertedrds released. [London? 1719?]; The whole life and dharacter of that beauteful, pions and ilustrous Princess Sobieski who is by proxy e'spou/s/d to the Cherelice. [London 1719?].

"Wydaje siç. że dominują w nicj utwory opistjące ze szlacleckicj perspektywy "obcego". jakim byl szkocki imigrant, zolnierz lub kranarz.

12 Zob. A. Bieganska. In Searth of Tolerance: Sattish Catholics and Preshyterians in Poland. "Scottish Slavonic Revicw" 17 (1991), s. 50.

${ }_{13}$ Postçpy kontrreformacji oraz incydenty nictolerancji wobec protestantów w Polsce omaxiam glównic za: J. Tazbir, Panstu be stosóm,..., op. cit.

${ }^{1+}$ Dwa najstynnicjsze spiski, .prochowy" (1605) oraz "papicski” (1678) przypisywano jezuitom, co przyczynialo siç do wybuchów histerii i przcśladowań katolików.
} 
rzecz ${ }^{15}$. W XVIII stuleciu, po głośnych wydarzeniach toruńskich (1724-1725), postawa ta grozila nawet bezpośrednią interwencją zbrojną. Po wycofaniu się Saksonii z przywództwa w świecie protestanckim (z powodu przejścia elektora na katolicyzm) Brytyjczycy wyznaczali takį rolę sobie, dążąc do stworzenia silnej unii państw protestanckich.

\section{Literackie paradoksy historii. Alegoryzacja Polski jako azylu „matki purytanizmu angielskiego”, Księżnej Suffolk}

Katarzyna Willoughby (1520-1580), wdowa po ściętym w hutym 1554 roku Henryku Grayu, księciu Suffolk, zwana „matką angielskiego purytanizmu”l6, w latach 1554-1559 tułała się wraz z rodziną po Europie, poszukując schronienia przed prześladowaniami ze strony kanclerza Stephena Gardinera (ok. 1482-1555), biskupa Winchesteru, przywódcy reakcji katolickiej w Anglii z ramienia ,krwawej” Marii Tudor. Ostatecznie znaleźli oni przystań w Polsce, na Żmudzi, dokąd zostali zaproszeni przez Zygmunta Augusta oraz wojewodę wileńskiego Mikołaja Krzysztofa Radziwilla „Czarnego”, dzięki wstawiennictwu (prawdopodobnie znanego sobie jeszcze z Anglii) reformatora religijnego, Jana Łaskiego. Uchodźcy pozostali tam do śmierci Marii Tudor (1558), po której mogli już powrócić do ojczyzny i odzyskać swe dobra z ręki nowej królowej, Elżbiety I. Ich pobyt w Polsce trwał w sumie dwa lata, od 1557 do 1559 roku. Z listów i zapisków wynika, że księżna Suffolk bardzo clıwaliła polską tolerancję i mądrość. Zwykła była mawiać, że ,ani Rzym, ani Augsburg nie są drogowskazem dla Polaków, ale Chrystus, który pozostawil Ewangelię"17.

Historia peregrynacji księżnej Suffolk, której ostatecznym celem okazała się Polska, po raz pierwszy w Anglii przedstawiono w opowieści hagiograficznej The Dutchess of Suffolke and her Husband Maister Bertic by' Gods Providence Priserved in Qu[een] Maries Time, prawdopodobnie pióra towarzyszącego jej męża, Richarda Bertiego ${ }^{18}$. Opis został dołączony do drugiego wydania Actes and Monmmentes... Johna Foxe'a, szeroko znanych jako Book of Martyrs

\footnotetext{
${ }^{15}$ Najgłośnicjsza. ale i najdziwnicjsza zbiórka pieniçdzy na rzecz polskich protestantów została zorganizowana w Anglii po wojnic pólnocnej. Do tego stopnia zdominowała ją gwaltowna dyskusja krytyczna na temat polskich protestantów (którym zwlaszcza zarzucano grzech wolncj clekcji, gdyż wybór wladcy leży tylko w kompetencjach Boga), ż sami zainteresowani znalcźli siç w cieniu. Zob. np. opozycyjne wypowicdzi: Th. Bennet. The case of the Reforme'd Episcopal Churthes in Great Poland and Polish Prussia consider'd in a Sermo preached on Sumday, Now. 18th, 1716 at St. Lamrence Jewry, London in the morning, and St Olave's Southwark in the Afternoen, London 1716; [M. Earbury|. A letter to the Bishop of Ely, upon the Ocasion of his suppos'd Late Charge (said to be Deliwerd at Combridge, Alugust 7th, 1716) as far as Relates to what is therein urg'd against

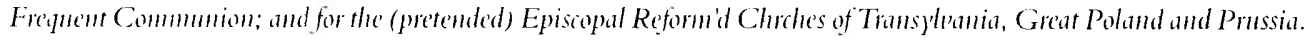
by Philalethe's, wyd. 2. London 1717. s. 28.

"Zob. K. L. Emerson. Wive's and Datughters: The Women of Sixternth Century England, Troy 1984. s. 245.

"I. Zins, Polska "w oczad Anglikón'.... op. cit. s. 132.

"sugerują to nicktóre źródla podane wartykule o nim w Dictionary' of National Biographly': Lady' Georgina Bertie's fire generations of a Loyal House, London $18+5$.
} 
(„Księga męczenników”) ${ }^{19}$. Jak wiele innych historii męczenników w zbiorze Foxe’a, opowieść o księżnej Suffolk układa się w schemat prześladowanej prawdy, która nienchronnie zatryumfuje w romantycznym porządku fabularnym: ucieczka - pogoń - powrót ${ }^{20}$. Opowiadanie opisuje szczegółowo przyczyny prześladowań księżnej', poszczególne odcinki pokonywanej przez nią wraz z rodziną drogi (drugie dziecko, nazwane Peregryn „Pielgrzym”, urodziło się w podróży), smutne i niebezpieczne przygody, a wreszcie szczęśliwe zakończenie - najpierw przystań w dobrach polskiego króla, następnie zaś rychly powrót do Anglii po śmierci prześladowczyni i odzyskanie dóbr dzięki wstąpieniu na tron protestanckiej władczyni. Opowieść wyraźnie słıży ukazaniu losów bohaterów pod egidą Boskiej Opatrzności, i polski król (wprawdzie dziçki wstawiennictwu protestanckiego poddanego) zdaje się w tym schemacie odgrywać rolę zasadniczą, jako ostateczny zbawca i opiekun znękanych wędrowców.

Względnie spokojnym przystankiem w dramatyczncj wędrówce stało się Mannheim na ziemiach elektora Fryderyka II (1482-1556, palatyna reńskiego od 1544 roku), jednak i tam w końcu uchodźcy zaczęli tracić nadzieję wobec wyczerpywania się środków do życia. Wtedy dotarły do nich listy od króla Polski (u Foxe’a brak imienia Zygmunta Augusta) oraz księcia litewskiego (wojewody) z zaproszeniem, które podniosło uclıodźców na ducluu, ale i zaniepokoiło. Perspektywę tę oceniali jako kuszącą, lecz niepewną. Do odleglego, nicznanego kraju podchodzili z nieufinością, trudno im było uwierzyć w rzeczywistą odmianç losu. Z niechęcią myśleli o opuszczeniu rodaków i znajomych dla obcego, nienawiedzanego przez Anglików miejsca. Podejrzewali, że moga po osiągnięciu celu podróży nie znaleźć tego, czego się spodziewają, że u kresu okaże się gorsza niż w punkcie wyjścia. Dlatego bardzo rozważnie planowali ten krok, i zwrócili się o radę oraz pomoc do przebywającego na emigracji w krajach niemieckich biskupa Barlowa (William Barlow, ówczesny biskup Bath i Wells, później z nominacji Elżbiety I biskup Chichesteru, zm. 1559), który zgodzil się im towarzyszyć, a wcześniej jeszcze wyruszyć do polskiego króla z podwójnym zadaniem okazania dziękczynienia i zdobycia dodatkowych gwarancji. Wysłali z nim resztki posiadanych klcjnotów. Barlow przywiózl wszelkie upragnione zapewnienia poświadczone królewską pieczęcią, a więc wypadało zaufać tej szansie i wyruszyć w drogę, co uczynili w kwietniu 1557 roku. Kolejny raz okazała się ona niebezpieczna i trudna. Jeszcze na ziemiach niemieckich Bertie w obronie własnej zranil pijanego kapitana, czego o malo nie przypłacił życiem. Dzięki wsparciu kolejnego panującego, księcia Erbachu (..Earl of Erbagh/”; był nim wówczas Eberhard, zmarły w 1559 roku) udało się wreszcie ponownie wyruszyć do Polski (nazywanej „Poléland" lub „Pooland”), i tym razem dotarli do niej bez przeszkód. Tam, podejmowani z honorami przez

\footnotetext{
"Zob. J. Foxe. Acts and Monmments of Martyes with Genewall discourse of these latter persentions, horrible monbles and tummltues, stimed up by Romish Prelate in the Churd, with diuers other things incident, especially to this rathe of Englande and Scotland, as partly also to other farraine mations, London 156,3 i nast. wyd.

2" Zob. I. Ribner, The English Hestory Play' and the Age of Shakesperane, Princenton 1957, s. 293.

21 Wyglądają onc bardzicj na osobiste porachunki niż powody religijne.
} 
króla, osadzeni w majątku Kroże na Żmudzi, żyli w spokoju aż do zgonu królowej Marii, po którym możliwy stał się powrót do ojczyzny i osiągnięcie nagrody za wytrwałość.

Kolejny raz historia księżnej Suffolk zainspirowala Thomasa Delaneya, który w 1602 roku wydat w zbiorze Strange Histories balladę The Dutchess of Suffolke Calamitie. Ballada tylko ogólnie wskazuje geograficzne punkty orientacyjne wędrówki księżnej z rodziną, ogólnie też przedstawia jej szczęśliwe zakończenie, sygnalizując odeskortowanie wygnańców do przyjaciela, księcia Kazimierza („Prince Cassemeer”) ${ }^{22}$. Trudno ustalić z całą pewnością, co skłoniło Delaneya do ominięcia nazwy miejsca azylu znalezionego przez księżnę. Czy polsko brzmiące imię księcia-opiekuna bylo jego własną inwencją, czy też autor zasugerował się postacią historycznego wielkiego księcia litewskiego (od 1440) i króla polskiego (od 1447), Kazimierza IV Jagiellończyka (1427-1492)? Może to jakiś daleki pogłos wieści o dokonanej właśnie w 1602 rokı kanonizacji syna Jagiellończyka, królewicza Kazimierza (1458-1484)? Czy może już wtedy, wobec zaostrzającego się obrazu Polski jako kraju katolickiego, prawdziwe imię wladcy mogło być niewygodne w spójncj, propagandowej wizji ratunku, którego protestanci mogli się spodziewać jedynie od wspólwyznawców, nie zaś od „papistów”? Na te pytania dotąd brak jednoznacznej odpowiedzi.

Dosyć jednoznacznie natomiast można w świetle współczesnych badań określić miejsce wyznaczone Polsce w sztuce Thomasa Drue The Life of Dutchess of Suffolke, wystawionej w teatrze „Fortuma” w sezonie 1623/1624, a wydanej w roku 1631.

Wspomniana ballada Delaneya wnosila w stosunku do historii Foxe'a kilka nowych szczególów, dodatkowo dramatyzujących fabulę, jak atak i ograbienie bohaterów przez zlodziei, motyw obecny również u Drue. Dlatego też uważa się ją, obok Book of Martyrs, za źródło jego sztuki. Istnieje jednak równiez hipoteza o oparciu The Life of Dutchess of Suffolke na treści wcześniejszej sztuki, The English Fugitives Williama I Ioughthona z roku 1600. Book of Martyrs byla częstym źródłem tak zwanych sztuk biograficznych, kwitnących w angielskim dramacie w końcu XVI wieku ${ }^{23}$. Jako produkcja lat dwudzestych sztuka Drue wydawać się może anachroniczna i epigońska, co pośrednio potwierdza w opinii niektórych badaczy hipotezę przepisania jej treści z The English Fugitives ${ }^{2+}$. Jeśli nawet tak było, zmiany dokonane dla wyeksponowania tu postaci palatyna („Palsgrafa”) musiały być i tak znaczne, gdyż mistyfikacja, w której Polska reprezentuje Palatynat, nie mialaby tu zadnego historycznego uzasadnienia. Sztuka Houghtona zaginęła i nie ma na jej temat żadnych pewnych informacji, istnieje nawet koncepcja, że jej tematem nie była tułaczka Księżnej Suffolk, lecz zagrożenia ze strony spoleczności angielskich katolików w Niderlandach. Pod pewnymi względami za polskim

\footnotetext{
22 ... And affermard conneyed the' were/l into their friend prince Cassemer" (Th. Delaney, Strange histories of Kinges, princes, Donkes, Lords, Ladyes, Kinights, and Gentelmen, London 1612 - pieśń 4, w. 145-146: „A następnie odeskortowani zostali / Do swego przyjacicla księcia Kazimierza”. Wszystkic fragmenty angielskic podajç w przypisach we whasnym thumaczeniu filologicznym).

${ }_{23}^{2 .}$ Uważa tak np. Irving Ribner, The English History' Play.... op. cit., s. 295.

${ }^{2+}$ Zub. ilidem.
} 
źródlem może dodatkowo przemawiać fakt, że I Ioughton był autorem w tym samym czasie sięgającym po inny wątek „polski”, w innej, również zaginionej sztuce Strange Neu's out of Poland, za która pobral honorarium wraz Peterem (?) Pettem. Ten ostatni prawdopodobuie dastarczał informacji, gdyż albo sam był w Polsce w misji dyplomatycznej, albo w wiedzę o niej wyposażali go inni czlonkowie rodziny, złożonej z handlowców ${ }^{25}$.

Możliwych jest kilka zazębiających się planów interpretacyjnych sztuki: protestancka i feministyczna parenetyka, romantyczny dramat plaszcza i szpady ${ }^{26}$, a takze - i ten odnosi się bezpośrednio do przedstawionego tu obrazu Polski - historyczny dramat protestancki, który modyfikuje historię, tak by mogła być czytana jako alegoria wypadków teraźnicjszy$\mathrm{ch}^{27}$. W tym ostatnim wymiarze dramat Drue miatby za zadanie na kanwie historii Księżnej Suffolk interpretować wspólczesne wydarzenia polityczne, w których istotną rolę odgrywała polityka zagraniczna Anglii. Opisywalby w istocie zdarzenia związane z bezpośrednimi przyczynami Wojny Trzydzicstoletnicj, bliskie angielskim protestantom ${ }^{28}$ : wybór przez Stany czeskie w 1619 roku „zimowego króla” Fryderyka V (1596-1632, od 1615 księcia-elektora Palatynatu Reńskiego) wraz z jego żona, córką angielskiego króla Jakuba I Elżbietą (1596-1662, elektorową od roku 1613), ich detronizację przez Ferdynanda II (1578-1637, od 1617 roku króla czeskiego, od 1618 węgierskiego, cesarza od tegoż 1619 roku) i tulaczkę z dziećmi po Rzeszy (podobnie jak Księżna Suffolk, Elżbieta urodziła dziecko w drodze), aż po azyl znaleziony przez nich w I Iadze, u dawnego adıiratora Stuartówny, namiestnika Niderlandów Maurycego Orańskiego (1567-1625). Jerzy Limon czyta The Life of Dutchess of Suffolke w kontekście innych sztuk stanowiących element politycznej kampanii przeciwko polityce Jakuba I, objawiającej się obojętnością dla sprawy protestanckicj (reprezentowanej przez Palatyna i Elzbbietę) oraz planami zbliżenia z katolicką Hiszpanią ${ }^{20}$. Zachowawcza i pokojowa polityka Jakuba I, który nie tylko nie wspieral jednoznacznie protestanckiej pary, ale nawet wyrażał wątpliwości wobec legalności elekcji Fryderyka V na czeski tron, spotkala się z krytyką angielskiej frakcji protestanckiej, której od 1623 roku patronowat, w opozycji przeciw ojcu, przyszły Karol I (160)(1649, król od 1625 roku).

Mistyfikacja, jakiej poddano droge do Polski w dramacie Drue, wyraźnie wspiera idę nieuchronnego zwycięstwa protestantyzmu na kontynencie europejskim, a więc nadzieje, jakie protestanci angielscy wiązali z „Zimową parą" ${ }^{30}$. W sztuce Drue występuje polski

25 Zob. R. B. Sharpe, The Real thar of the Theatres: Shakespear's Fellou's in Rivalyy uith the Adminal's Men, 1594-1603; Repertories, De'ices, and Type's, Boston, 1935, s. 177-179.

2t. Zob. ibidem. s. 32.

${ }^{27}$ Zob. ibide'm.

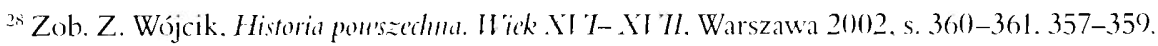

2" Zob. J. Limon. Dangerous maters, Cambridge 1985, s. 21-41.

${ }^{3 \prime \prime}$ Warto zauważyć, że sztukę Druc wystawiono w teatrze będącym pod opicką .zinowego króla” w czasic jego pobytu w Anglii (Palsgrafe's Compun $)^{\prime}$ ). Opisywany w sztuce Palsgraf to jego dziadck, dziçki czemu tym bardzicj może być z „zimowym królem” identyfikowany, a szczegól ten wyjaśnia jednoznacznic rolę tej sztuki jako elementu ówczesncj kampanii antykrólewskicj i uzasadnia lepicj panegiryczny kontckst dzicła. 
król i mowa o Polsce, jednak ta ostania zdaje się leżeć w dominium Palsgrafa, i on właśnie, a nie Zygmunt August, udziela azylı wygnańcom. Po raz pierwszy pojawia się on w akcie I w charakterze obranego właśnie króla Polski, który pretenduje jako najgodniejszy kandydat do ręki owdowialej Księżnej ${ }^{31}$. Jego awanse zostają odrzucone na rzecz romantycznego uczucia księżnej do jednego z czlonków świty, i „Polski Król” wycofuje się bez urazy do swych włości. Kolejny raz pojawia się ta postać w V akcie sztuki. Udzielając schronienia swojej dawnej miłości i jej bliskim, broni jej przed agentami Marii Tudor oraz Ligi, i nadaje uciekinierce we wladanie ziemie na Żmudzi (znane już z Foxe’a). Polska w granicach Palatynatu Reńskiego, w której niemiecki jest domyślnym językiem komunikacji, a król - palatynem, to oczywiście czytelny zabieg szyfrujący. Z jednej strony autor alegoryzuje czyn Czechów, którzy w 1618 roku obrali swym władcą Fryderyka V, w obrazie Polaków, którzy rzekomo mieli to samo uczynić z jego przodkiem. Z drugiej strony nobilitująco i legitymizująco przedstawia samego Fryderyka V jako potomka królewskiego rodı, a więc jak najbardziej godnego pozycji króla Czech. Sens anachronizmu (Zygmunt August jako władca elekcyjny) staje się czytelny tylko w aktualnym, nobilitującym całą dynastię kontekście. Sztuka pomija kwestię przynależności Polski do obozu katolickiego, pozwalając na wtórną identyfikację Palatyna-obrońcy księżnej Suffolk ze wspomnianym wyżej opiekunem Elżbiety i Palsgrafa, autentycznym księciem Maurycym Orańskim, który wbrew decyzji elektorów niemieckich przyjmowal pod opiekę ,Zimową parę” ${ }^{232}$. Wydaje się, że zasadniczy jest tu fakt wolnej elekcji, który spelnia funkcje legitymizacji władzy, i w tym znaczeniu Polska reprezentuje w dramacie monarchię pełnoprawną, monolityczną. Doraźnie i w celach instrumentahnych autor występuje przeciw rozpowszechnionej w monarchiach dziedzicznych pogardzic do władców i monarchii elekcyjnych. Z drugiej strony czyni to na sposób brytyjski, podkreślając dynastyczne, dziedziczne prawa kandydata do tronu ${ }^{33}$.

Tak więc po kilkudziesięciu latach polski akt tolerancji odżył w nowym, literackim, a tym samym paradoksahnym kodzie historycznym, w którym fakt azylu udzielonego księżnej Suffolk przez katolickic, tolerancyjne państwo, azylu, na który nie mogla ona liczyć w protestanckim Palatynacie Reńskim, wspierał jedynie pobożne życzenia Anglików o nieuchronnym zwycięstwie protestantyzınu. Natomiast hagiograficzna historia pobytu księżnej Suffolk w Polsce, jako dowód Boskiej Opatrzności, choć bez najmniejszego pozy-

${ }^{31}$ Jerzy Limon odnalazl pewne uzasadnienic dla tego wątku w legendzie rodziny Suffolk o bezskutecznych staraniach Zygmunta Augusta o rękę piçkncj Katarzyny (zob. ibide'm, s. 42).

32 Por. A. H. Tricomi. Re'ading Tudor-Stmatr Texts through Cultural Historicism, Gainesville 1996, s. 153.

${ }^{33}$ Alegoria polskicgo króla i Polski jako reprezentacji Anglii osiągnie popularność w sztukach i gatunkach satyrycznych czasów Rewolucji P'urytaniskicj oraz Restauracji, zwlaszcza w litcraturze tzw. „spisku papieskiego" z lat 1678-1683 - zob. B. Cieszyńska, Konterfekt Polski i Polakóu' u' sutyrze angielskiej przetommu

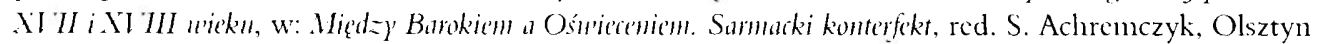
20102: cadem. Liberty or Chaos? Allegory of Poland in Restoration Drama and Satire. Philological Rescarch and Studies, .English Language and Literature Series University of Piteşti - Faculty of Letters” (Romania). No. $1 / 2005$. 
tywnego komentarza pod adresem kraju, powracala w skróconej formie w kolejnych wersjach i kontynuacjach angielskiej „Księgi Męczenników” aż do końca XVIII wiekü ${ }^{3+}$.

\section{Szkoci w Polsce. Meandry tolerancji religijnej}

Społeczność szkocka w Polsce w XVII wieku wzrosła znacząco. Osiedlali się tu i katolicy, i protestanci, szukając lepszych warunków życia lub wolności religijnej ${ }^{35}$. Brytyjscy autorzy zwykle chwalili Polskę jako ,matkę gotową wykarmić rzesze szkockich handlarzy"36, jednak analiza tego zagadnienia prowadzi nas do interesującego antykatolickiego dialogu, mającego w XVII wieku aż trzy wersje, którego akcja dzieje się w Polsce i zawiera aluzje do polskicj tolerancji. Jako pierwszy opracował tę satyrę szkocki arystokrata James Sempill i wydał jq w 1624 roku w Aberdeen jako The Pack-Man Pater Noster or a Dialogne Betu'ixt a Chapman and a Priest, mistyfikując tekst jako przeklad z holenderskiego (.Neulie translated out of Dutch"). W dialogu tym szkocki domokrąża (Pack-Man, Chap-man, Pedler, Pedlar) przybywa do katolickiego księdza imieniem Jan, by przeprowadzić z nim dyskusję na tematy dogmatyczne, takie jak lacińskie modlitwy, pośrednictwo świętych oraz autorytet papieza:

\section{A Polands Pedler l'ent upon a day, \\ Unto his Parish Priest to learne to pray. \\ The Priest sayd: Packe-man, thou must hant the Closter, \\ To learn the Ave and the Pater Noster ${ }^{37}$.}

Stylizowany na naiwnego rozmówcę Handlarz sokratejską metodą pozwala najpierw odczuć księdzu jego „uczona przewagę”, by w końcu, zaskakując go erudycją, odnieść w dyskusji miażdzące zwycięstwo. Wzbudza nawet podejrzenia duchownego, ze strój i pakunek handlarza to jedynie przebranie, naprawdę zaś jest on kalwińskim czy luterańskim mnichem, przysłanym zza morza, by rozsiewać reformacje ${ }^{38}$. Argumenty I Iandlarza maja zdecydowanie kalwińskie podłoże, jednak zaprzecza on tym oskarżeniom, kontynuıjąc swoje tyrady, aż wreszcie dość bezradıy Ksiądz Jan proponuje mu powrót następnego dnia na rozmowę z opatem, jako lepicj przygotowanym do dyskusji. Plan ten okazuje siç katastrofą.

\footnotetext{
${ }^{34}$ Por. na przyklad: The Book of Martyes, with an. Acount of the Aits and Momuments of Churde and State, from the Time of Our Ble'sed Saliour, to the Year 1701,.., t. 2, London 170)2. s. 338.

35 Zob. A. Bieganiska, The learned Soots in Poland (from the mid-sixtecuth to the dose of the eightechth century), "Canadian Slavonic Papers" 43 (20)(1), nr 1.

3t W. Lightow. The Totall Disconrse, of the Rare Aderntures, and Paincfull Peregrinations of Long Vincteene Teras Traveiles from Sotland to the Most Famous Kingdomes in Lamope, Asia, and Africa..., cz. 9, 16+1).

37 .Pewnego dnia w Polsce I Iandlarz / przybyl do ksiçdza proboszcza na naukę modlitwy. / Rzekl Ksiądz: Handlarzu, musisz nawicdzić klasztor, / by nauczyć siç Zdrou'aś i Ojoze masz:"

${ }_{3 *}^{3 *}$ Pragnç podziçkować Arthurowi H. Williansonowi za ukazanic mi kontckstu kulturowego tego fragmentu.
} 
Gdy następnego dnia odświętnie ubrany Handlarz, z nieodłącznym tobolkiem na plecach, powraca do klasztoru, opat krzyczy na nich obu, nazywając i Księdza Jana, i Handlarza heretykami, nie zawahawszy się nawet przed przymusowym wyedukowaniem szkockiego niedowiarka. Następuje scena próby sil, w której opata wspiera jego pomocnik-osiłek, jednak Ilandlarzowi udaje się (chociaż za cenę utraty torby z towarami) wyrwać i uciec z klasztoru. Odchodzi stantąd rozczarowany, zawiedziony i ostatecznie przekonany, że nie ma szansy na porozumienie z katolikami.

W roku 1641 stynny angielski poeta, John Taylor, "Water-Poet”, popetnil plagiat ${ }^{39}$, wykorzystując dialog Sempilla w utworze. A Pedlar and a Romish Priest in a Very Hot Discourse, full of Mirth, Truth, Wit, Folly, and Plain-dealing. Jako anglikanin przeredagowal zawartość dogmatyczną dialogu Sempilla, usuwając z niego również najsilniejsze szkockie akcenty, pozostając zarazem dość wierny oryginałowi. Z perspektywy obrazu Polski jako miejsca prowadzenia dyskusji religijnej jest to jednak zupetnie inny dialog. Ksiądz Jan podkreśla wyjątkowa pozycję Polski w stowach:

Wert thou at Rome, and half these words didst speak,

Pedlar, it were chough thy neck to break;

But here you live, and talk and prate secure,

And undernalue that blest I irgin pure,

Yeelding no honour, or no adoration

To her, or to her dayes of celebration

(Goe but to Spaine, and she'u' thy vild condition,

Thou shalt be tortur't in the Inquisitions) ${ }^{40}$.

Na drugim biegunie znajdụją się Rzym i I Iiszpania Inkwizycji; w tym nowym ujęciu gwałtowna końcowa scena dialugu Sempilla zostala całkowicie pominięta. W satyrze Taylora Handlarz nie widzi konieczności powrotu do klasztoru, i choć rozstaje się z Księdzem Janem przekonany o swej racji, dzieje się to w pokoju, Polska zaś zyskuje pozycję jedynego miejsca w katolickim świecie, w którym możliwa jest religijna dyskusja bez obawy prześladowań.

Uzasadnienie zmiany dokonanej w szkockim dialogu Sempilla przez angielskiego poetę nie jest na razie jednoznacznie mozliwe w świetle znanych faktów z jego życia. Możemy wskazać jedynie kilka tropów zblizających nas do odpowiedzi. Wśród nich najważniejszym wydaje się założenie, że Taylor miał pozytywne doświadczenia, związane z Polską jako kra-

\footnotetext{
3" Zob. L. H. Kendal. Jr. Johm Taylor's Piracy of The Patk-Mans Puternoster, „Papers of the Bibliographical Socicty of America" (College Park. MD)), 57: 19633, s. 201-210.

+"..Gdybyśs byl w Rzymic. i polowy tych stów wypowiedzianych / starczyloby. Handlarzu. by ci skręcić kark. / Ale mieszkasz tutaj i mówisz. i bluźnisz bezpiecznic. / i Dziewicy czystej i blogosławionej ubliżasz, / nic okazując nddania ani czci/ani dla Nicj samej, ani dla jej świąt. / (Lecz idź do I Hiszpanii i okaź swoją naturę dziką. / a będziesz torturowany przez Inkwizycję)".
} 
jem tolerancyjnym, podczas jego podróży do Czech, którą odbył, by wesprzeć protestancką sprawę Elżbiety i Palsgrafa ${ }^{+1}$. W tym kontekście nie można wykluczyć również wpływu historii Księżnej Suffolk w Actes and Monumentes Foxe'a lub w sztuce Drue.

Wydaje się jednak, że w świadomości Brytyjczyków (a przynajmniej Szkotów) większe szanse utrwalenia mial obraz Polski przywolany przez Sempilla ${ }^{+2}$. Podczas gdy brak wznowień wersji dialogu pióra Taylora, dialog Jamesa Sempilla, w redakcji jego syna Roberta - poszerzony i z jeszcze agresywniejszą argumentacją antykatolicką - byl do końca wieku wydawany jeszcze trzykrotnie ${ }^{43}$.

Znacznie silniejszy niż dialogi Sempillów wpływ na opinię publiczną w Wielkiej Brytanii miały Neus from Poland... - Wícści z l'olski, świadectwo ministra kalwińskiego Gilberta Eleazara, który słuzyl angielsko-szkockiej kongregacji w Wilnie i był tam świadkiem zburzenia zboru kalwińskiego w roku 1640. Początkowo zachwycony koegzystencją tylı wyznań w Polsce, pod wplywem wypadków wileńskich swoje New's from Poland: Wherein is Declared the Cruell Practice of the Popish Clergie Against Protestants... ${ }^{+4}$ opatrzyl Eleazar wezwaniem na stronie tytutowej: „Read it over; and you shall find it a most mupardled story for harbarous Treaderie” — „Przeczytaj to, a znajdziesz historię najbardziej barbarzyńskiej zdrady". Jego ksiązeczka nie pozostawiala wątpliwości co do trudnej sytuacji protestantów w Rzeczypospolitej. Sam autor opisywal doznane kilkakrotne prześladowania, raz pocięto go nawet za swoją protestancką slużbę „polską szablą", tak ze istniala obawa o jego życie. Winą za wydarzenia wileńskie obarczał „papistów” i jezulitów. Uważał, że przebiegłość katolicka polegała na tym, że nawet zakomnice składały fałszywe przysięgi na potwierdzenie winy protestantów, co przyczyniło się do zakazu praktykowania tej religii na terenie Wilna oraz publicznej kaźni rzekomych sprawców. Prowidencjalne myślenie autora objawia się między innymi w przekonaniu, iz Bóg potwierdził krzywoprzysięstwo zakonnic, uśmiercając jedną z nich atakiem apopleksji. Jezuici, niczym zazdrośni i wyuczeni w sztıce prowadzenia perfidnej gry szermierze, zdają się tu podstawową sprężyną działania, uderzając w naiwnych i prostych protestantów, którzy za tarczę mają jedynie wlasuą prawdę. Ich wpływowi na króla i ograniczeniu protestantom dostępu do niego przypisał Szkot negatywny wynik procesu. Przypadkowe zdarzenie, utrącenie gzymsu w kościele kato-

\footnotetext{
${ }^{+}$Por. B. Capp, The ITorld of Jolen Tiylor the Witter-poet 1578-16.53. Oxford 1994. s. 127. Lyle H. Kendal (Jolm Taylor's Piracy..., op. cit., s. 2(12) mówi o dwu edycjach Ruberta Sempilla w 1669 (Edynburg. Glasgow) i kolejnej w 1690.

t2 O rzeczywistym charakterze oraz ilości incydentów polsko-szkockich w Polsce zob. A. Biegańska, In Search of Tolerance.... op. cit., s. 44-47. Przegląd jej wskazuje, że nie bylo ich duzo i rzadko byly poważne.

t3. Prawdopodobnic pierwsza edycja dialogu Roberta Sempilla zostala przygotowana w roku $163+$ (zob. L. H. Kendal, Johun Taylor's Pirucy..., op. cit., przyp. na s. 2(1-t) ale zachowala siç wersja: A Pick-Tooth for the Pope: or, The Pack-Mans Pater Noster. Set Dou'me in a Dialogue, Betwixt a Park-Man, and a Priest. Trumslated ont

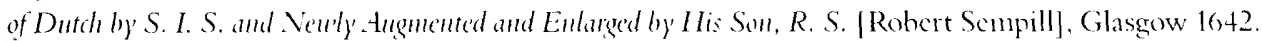

${ }^{+}$Zob. G. Eleazar. Nen's from Poland: Itherein is Dedared the Cruell Practice of the Popish Clergie Aguinst the

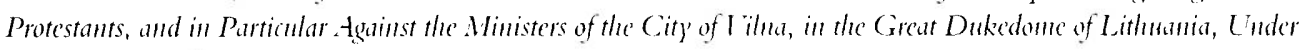
the Golerment of the Most Illustrous Prince, Duke Radzine'll... London totl.
} 
lickim przez strzelające do kawek dzieci, wykorzystano jako pretekst do rozpętania nagonki na protestantów, i zostali oni skazani na kaźń, której udalo im się uniknąć tylko dzięki pomocy Krzysztofa Radziwilla (1585-1640, wojewody wileńskiego od 1633 roku).

Incydent wileński w rozważaniach Eleazara uzyskał szerszy kontekst, zarówno religijny, jak i spoleczno-polityczny. Przede wszystkim autor nie pała nienawiścią do katolicyzmu, nie jawi się jako fanatyk nienawidzący wszystkich katolików. Podkreśla, jak wiele lączy oba wyznania. Ale z jego obserwacji, poczynionych podczas trzyletniego pobytu w Koronie i na Litwie, wyłania się obraz Polaków niedouczonych, bezrefleksyjnych, niezdolnych do twórczej analizy swojego wyznania, biernych i skupionych raczej na zewnętrznych niz wewnętrznych oznakach wiary. Ta nieświadomość, a zarazem uczuciowość, w oczach Szkota czynią Polaków i Litwinów podatnymi na iluzję oraz zbrodnicze wplywy zazdrosnych o swą pozycję jezuitów. To wlaśnie polskiemu bezwladowi umysłowemu przypisuje minister tak silny wplyw nieuczciwych „papistów”, skupionych na sukcesie, a nie religijności. Na tle bezmyślnej bierności religijnej katolików w Rzeczypospolitej postacie niedawno zmarlego Krzysztofa Radziwilla oraz jego syna Janusza (1612-1655) urastają do rangi obrońców prawdziwej wiary i filarów protestantyzmu.

Autor dążył do uzyskania jak najbardziej obiektywnej perspektywy poprzez przytaczanie dokumentów i wyważony, choć jednoznaczny pod względem moralnym komentarz. Sam fakt prześladowań uznał za ważny składnik duchowego rozwoju chrześcijanina, i nie miał wątpliwości, że dokonane zto uszlachetniło niewinne ofiary, a zaszkodzilo prześladowcom. Obserwacje poczynione na naszych ziemiach nakazały Eleazarowi wypełnić swą sprawozdawczą i refleksyjną książeczkę również radami dla protestantów w ogóle, a w szczególności dla tych we własnym kraju. Poznawszy jezuitów i katolików (s. 29-31), stwierdza on, ze najlepszym krokiem miłıjących jedność protestantów jest zakaz wszelkich katolickich i sekciarskich praktyk oraz pozbycie się „ekstremistów” z Kościoła anglikańskiego i królestwa. Modli się zatem o jedność, zarazem jednak nie widzi szansy na tolerancyjne wspólistnienie; jedyna droga to usunięcie wszystkiego, co zagraża jedności religijnej w królestwie jednego monarchy. Znajomość relacji między katolikami a protestantami w naszym kraju pokazała mu, jak wielką wagę nua zachowanie zgody w kościele reformowanym, ograniczenie powstawania i działania nowych sekt, potrzeba zaprzeczenia argumentowi katolików, iz istotą protestantyzmu są podziały i ze nie ma wśród nich zgody. Pisał to zatroskany protestancki minister u progu wojny domowej i rewolucji, mającej w Anglii wymiar tyleż polityczny, co religijny.

Drugie wydanie Wiéści z Polski Eleazara z roku 1652 znalazło szerszy oddźwięk w brytyjskiej opinii publicznej, spełniając pewną funkcję propagandową. Wraz z utworami przedstawiającymi prześladowania protestanckie po "potopie"

\footnotetext{
t5 Por. The Book of Martyrs... Wherein is gien'th a Faithful Relation of the Sufferings and Martyrdoms of the Apostles, En'angelists, and Primitive Christians, whder the Ten Heathen Persecutions, and of the Ami-Christian Popish Persecations that hane been in Poland, Lithamia..., op. cit.; R. Burton, Martyrs in Flames, or, The History of Popery Displaying the Horrid Persectitions and Crueltic's Exercified upon Protestants by the Papists, for . Many Hundred Years past..., wyd. 3, London 1729.
} 
rzecz protestantów polskich po wojnie pólnocnej ${ }^{t h}$ stanowiły one kontekst dla piśmiennictwa związanego z angielską reakcją na „krwawą laźnię toruniską” z roku 1724. Opisy zdarzeń w Toruniu rozsyłane przez dwór pruski zainspirowaly lawinę polennicznych tekstów thumaczonych oraz oryginalnych. Zazwyczaj pisane byly silnie zretoryzowaną prozą ${ }^{\$ 7}$. Wśród nich wyróżnia się formą i treścią poemat anonimowego szkockiego autora zatytulowany A Poem Upon a Tragedy of Thom. Jest to wzruszająca poezja „świadka emocjonalnego”, zapis głębokiego przeżycia, zaskakującego silną identyfikacją anonimowego autora z Polską. Caly poemat, hiperbolizujący wymiary zdarzenia, ulegał propagandzie augustowskiej, ze jedynymi odpowiedzialnymi za wypadki toruniskie byli jezuici i magnaci ${ }^{+\$}$ :

Yet Justice does require, that w'e

Unto the World shou'd shou',

That these Seterities do not

From King Augustus flou;

But from Grandees and Jesuites,

Whose malice is so keen,

They torture Lau's, to make the'm spe'ak

What they did never mean ${ }^{+\prime}$.

Najwięcej wersów poświęcil autor opisowi magnatów polskich jako wrogów Augusta II, nieustamnie spiskujących dla materialnych korzyści. Wyższość króla nad nimi oddaje za pomocą pytania retorycznego:

Is't possible, that they can be

To King Angustus Friends,

Whose Conduct does alienate

From him the Peoples Minds?

Możnowładców wini antor za wydarzenia toruńskie bardziej od jezunitów, posuwa się nawet do oskarżenia o sprowokowanie „masakry”, przez rywala Sasa, Stanisława Leszczyńskiego:

to Patrz przyp. 15.

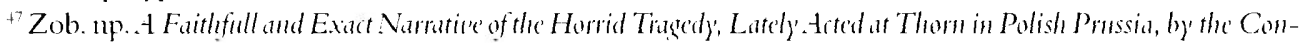
tristance and Instigation of the Jesuits. London 1725.

${ }^{4 *}$ Por. E. Rostworowski, Historia pou'szechna. It'ick XI 711, Warszawa 20(2), s. 266.

" "Jednakże Sprawiedliwość n’ymaga, byśmy pokazali światu, /ze te prześladowania/nic od króla Augusta plyną. / lecz od magnatów oraz jezuitów. / których krwiożcrezość jest tak wiclka. / że torturują prawa, by zaczęly mówić, / o tym, czego nigdy nie oznaczaly" (s. 8).

5" "Czy to możliwe, żcby byli / przyjacióhni króla Augusta, / którcgo przywództwo oddala go / od umyslów narodu?" (s. 9). 


\section{Should we not be afraid, that thus, \\ Some dark and hellish Plot \\ By Stanislaus is contriv'd, \\ his Intrest to promote?}

Z przedmowy i końcowego komentarza wydawcy, obecnego przy powstawaniu poematu i podpisanego inicjalami „I. P.”, czytelnik dowiadıje się, jak wstrząsającym doświadczeniem był dla anonimowego autora, jego przyjaciela, podjęty w poemacie temat. Utwór mial się narodzić jako bezpośrednia reakcja na lekturę przysłanego do Edynburga w celu przedrukowania opisu A Faithfull and Exact Narrative of the Horrid Tragedy, Lately' Acted at Thom in Polish Prussia... 52. Nadmiar emocji spowodowat, że gdy w refleksji poeta dotarł do obrazu klęski czekającej Polskę z winy wielnnożów, zmuszony był przerwać, a po uspokojeniu się był juz jedynie w stanie sformulować stowa dołączonej do poematu modlitwy. Cały utwór wskazuje na silną identyfikację poety z Rzecząpospolitą, znajomość związanych z nią faktów i wyrobiona o nich opinię, czego z cała pewnością nie mógl przejąć z przeczytanego pruskiego opisu. Pisat on jakby z polskiej perspektywy geograficznej i emocjonalnej, z dużym zaangażowaniem, zaznajomiony z sytuacją w Polsce, zaniepokojony o jej przyszłość. Magnaci polscy spiskują tu przeciw .jego królowi”, rujnując „naszą ojczyznę”. Dotąd nie udato się zidentyfikować autora A Poém L pon a Tragedy' of Thorn, jednak analiza tekstu wskazuje, że jego poemat o wypadkach toruńskich pozostawał w ścisłym związku z innymi, bardzo możliwe, że bezpośrednimi doświadczeniami z Polski $i^{53}$.

Przybywający do dawnej Polski mieszkańcy Wysp Brytyjskich pozostawiali czasem literackie ślady, pisane ich wlasną ręką lub w postaci inspirujących innych pisarzy motywów literackich, w którym fakty historyczne uzyskiwaly nowy, ideologicznie nacechowany sens. Te literackie okruchy wiązały się znacząco ze zmieniającym się obrazem Rzeczypospolitej jako „państwa bez stosów”. Szesnastowieczna sława tolerancyjnej Polski, której niepodważalnym dowodem z perspektywy brytyjskiej wydawała się historia azylu udzielonego księżnej Suffolk, zaczęla bledną̧́ w obliczu postępów kontrreformacji, wraz z coraz silniejszą identyfikacją Rzeczypospolitej z obozem jezuickim, papieskim. Zaowocowało to większą wrażliwością Brytyjczyków na losy polskich immowierców, a także w ich silniejszych

\footnotetext{
"Czy nic powinniśny siç obawiać, ze tym sposobem / jakiś ponury i pickiclny spisck / obmyślony zostal przcz Stanisława. / by promowac jego interesy?" (s. 9).

5. Patrz przyp. 47.

${ }^{53}$ Tak silna identyfikacja podmiotu z Polską nuże wskazywać na urodzenic w niej lub zamieszkanic. Jednak zagadnicnic to wymaga dalszych badań.
} 
reakcjach emocjonalnych, filozoficznych i politycznych. Dotyczyło to zwłaszcza licznic przybywających do Polski Szkotów, z reguły wyznawców kalwinizmuı.

W grupie tekstów stanowiących reakcję na akty polskiej nietolerancji, wyróżniają się dwie przeciwne perspektywy. Dziełko Gilberta Eleazara reprezentuje jeden biegun propagandowy, podejnując temat prześladowań polskich protestantów nie tylko w celu krytyki Polaków, ale przede wszystkim dla dobra Anglii i protestantyzmu, by uczyć współrodaków w oparciu o polski przyklad. Biegun przeciwny, pełnej identyfikacji z Polską i jej losem, reprezentuje anonimowy poemat o wypadkach toruńskich, skupiony na dramacie rozdartego wewnętrznie kraju, utwór pisany dla jego dobra, świadectwo troski autora o - być może przybraną - ojczyznę. 